\title{
JUDICIAL RETRENCHMENT UNDER RULE 10b-5: AN END TO THE RULE AS LAW?
}

The extended stock market slump of the early $1970 \mathrm{~s}^{1}$ caused many corporations to reconsider the advantages of public ownership. A number of corporations reacted to depressed stock prices by "going private"2-withdrawing their stock from active public trading through a tender offer or merger, ${ }^{3}$ thereby "squeezing out" minority shareholders and freeing the corporation from regulation by the Securities and Exchange Cominission. ${ }^{4}$ This wave of going private transactions has been

THE FOLLOWING CITATIONS WILL BE USED IN THIS NOTE:

A. Bromberg, Securimes Law: Fraud, SEC Rule 10b-5 (1967, with Supps.) [hereinafter cited as BROMBERG]; Loss];

L. Loss, Securities Regulation (2d ed. 1961, Supp. 1969) thereinafter cited as

Securities Act of 1933, 15 U.S.C. $\$ \S 77 a$-aa (1970) [hereinafter cited as 1933 Act];

Securities Exchange Act of 1934, 15 U.S.C. $\$ \S 78 \mathrm{a}-\mathrm{jj}$ (1970) [hereinafter cited as 1934 Act];

Securities Exchange Act of $1934 \S 10(b), 15$ U.S.C. $\S 78$ j (1970) [hereinafter cited as section $10(\mathrm{~b})]$;

Securities Exchange Act Rule 10b-5, 17 C.F.R. \$ 240.10b-5 [hereinafter cited as rule $10 \mathrm{~b}-5]$.

1. In January, 1973, the Dow Jones Industrial Index stood at a record high of 1051. By October, 1974 the Index stood at 577-its lowest since 1962. N.Y. Times, Oct. 4,1974 , at 53 , col. 6 .

2. "Going private" has been the subject of considerable recent commentary. See, e.g., Borden, Going Private-Old Tort, New Tort or No Tort?, 49 N.Y.U.L. REv. 987 (1974); Brudney, A Note on Going Private, 61 VA. L. Rev. 1019 (1975); O'Neal \& Janke, Utilizing Rule 10b-5 for Remedying Squeeze-Outs or Oppression of Minority Shareholders, 16 B.C. IND. \& CoM. L. Rev. 327 (1975); Note, Going Private, 84 Yale L.J. 903 (1975); "Going Private": A Lesson in Corporate Responsibility, Address by SEC Commissioner H.A. Sommer, Jr., Law Advisory Council Lecture, Notre Dame Univ. Law School, Nov. 1974, reprinted in [1974-75 Transfer Binder] CCH FED. SEC. L. REP. $\Uparrow$ 80,010.

The SEC currently has under consideration proposed rules which would govern going private. See Proposed Rules $13 \mathrm{e}-3 \mathrm{~A}$ and 13e-3B, Exchange Act Release No. 11231 (Feb. 6, 1975), 2 CCH FED. SEC. L. REP. ITा 23,704-05, explained in Sccurities Act Release No. 5567 (Feb. 6, 1975), [1974-75 Transfer Binder] CCH FED. SEC. L. REP. If 80,104. At present, no hearings on the proposed rules have been scheduled. Telephone conversation with Office of the Secretary, SEC, August 23, 1976.

3. Other techniques which may be used to go private include a sale of assets or a reverse stock split. See O'Neal \& Janke, supra note 2. See F. O'NeAr, "SqueezeOUTS" OF MiNORITY SHAREHOLders 57-408 (1975) for a detailed discussion of the various techniques available.

4. Section $12(\mathrm{~g})(1)$ of the 1934 Act, 15 U.S.C. $\$ 78 l(\mathrm{~g})(1)$ (1970), requires corporations with total assets over $\$ 1,000,000$ and inore than 500 shareholders to register 
accompanied by increasing recourse to the federal courts by disappointed minority shareholders who had purchased stock at higher prices during inore prosperous times and subsequently found themselves outside the corporation, holding only a clain to the current inarket value of their former equity interest.

Squeezed-out minority shareholders have inet with success in two recent Second Circuit decisions, Marshel v. AFW Fabric Corp. ${ }^{5}$ and Green v. Santa Fe Industries, Inc. ${ }^{8}$ The solicitude shown the plain-

with the Securities Exchange Commission. Once registered with the SEC, a corporation must comply with section 13 (requiring periodic reports) and section 14 (regulating proxics), 15 U.S.C. $\S \S 78 \mathrm{~m}-n$ (1970). Expenses associated with remaining public and complying with the reporting requirements have been estimated to be as high as $\$ 100,000$ per year. Heishman, Going Private-Or How to Squeeze Investors, Dus's ReviEw, Jan. 1975, at 37. For a more complete discussion of the rule and the cost of compliance, see Swanson, The Elimination of Public Shareholders: Going Private, 7 CoNN. L. REv. 609, 613-17 (1975). Mr. Swanson, a staff attorney with the SEC, offers several expense estimates from SEC hearings and from correspondence the SEC has received from corporations. Id. at 615.

5. 533 F.2d 1277 (2d Cir.), petition for cert. filed, 44 U.S.L.W. 3720 (U.S. June 8, 1976). In Marshel, the plaintiff was one of some 1,000 public shareholders who owned approximately 32 percent of Concord Fabrics, Inc. The other 68 percent of the stock was owned by the Weinstein family. Although the stock was issued at $\$ 15$ per share, by late 1974 the shares were trading at $\$ 1$. The Weinsteins resolved to take Concord private by organizing a shell corporation, AFW, to which they transferred their Concord stock in return for 100 percent of the stock of the new corporation. Their initial plan called for a tender offer, to be followed by the merger of AFW and Concord, thus "squeezing out" the nontendering shareholders, who were to receive $\$ 3$ for their shares. Since approval of the merger by shareholder vote was a foregone conclusion because of the Weinstein holdings, Marshel sought an injunction in federal district court to halt the merger. The district court denied plaintiffs' motion for a preliminary injunction. Marshel v. AFW Fabric Corp., 398 F. Supp. 734 (S.D.N.Y. 1975). On appeal from the denial, the Second Circuit reversed the district court's judgment. 533 F.2d 1277 (2d Cir. 1976). Writing for the court, Judge Hays held that the use of corporate funds by majority shareholders for the sole purpose of eliminating minority shareholders operated as a fraud and therefore constituted a violation of rule 10b-5 (see text of rule at note 7 infra). In a companion case in the state courts, the New York Attorney General sought and obtained an injunction against the merger. People v. Concord Fabrics, Inc., 83 Misc. 2d 120, 371 N.Y.S.2d 550 (Sup. Ct.), aff'd - App. Div. 2d -, 377 N.Y.S.2d 84 (App. Div. 1975).

6. 533 F.2d 1283 (2d Cir.), petition for cert. filed, 44 U.S.L.W. 3671 (U.S. May 14, 1976). In Green, Santa Fe Industries, the 95 percent owner of Kirby Lumber Co., transferred its Kirby stock to the newly organized Forest Products, Inc., in exchange for all the new company's stock. Pursuant to the Delaware short-form merger statute, Del, Code ANN. tit. 8, § 253 (1975), the Board of Directors of Forest Products authorized a merger with Kirby which eliminated Kirby's minority shareholders and allowed them $\$ 150$ per share for their stock. Claiming that the fair value of his stock was some $\$ 772$ per share, Green brought suit for rescission of the merger and for damages. The district court dismissed the complaint for failure to allege any nondisclosures by defendants. Green v. Santa Fe Indus., Inc., 391 F. Supp. 849 (S.D.N.Y. 1975). The Second Circuit reversed, holding that the use of the short-form merger for the sole purpose 
tiffs' claims under section 10(b) and rule 10b-5 in Marshel and Green is typical of the expansive 10b-5 jurisprudence of the 1960 s and early 1970s. This Note will discuss the viability of continued expansion of 10b-5 relief in light of two recent Supreme Court decisions which indicate a more restrictive attitude toward private actions under $10 \mathrm{~b}-5 .^{8}$

of eliminating the minority sharehoiders constituted a breach of the majority's fiduciary duty and thus vioiated ruie 10b-5. 533 F.2d 1283 (2d Cir. 1976). The court's opinions in Marshel and Green emphasized that the primary objection to the defendant's action was that it lacked a corporate purpose and benefitted only the controlling sharehoiders. 533 F.2d at 1280-82; 533 F.2d at 1286-88, 1290. Green distinguished Popkin v. Bishop, 464 F.2d 714 (2d Cir. 1972), on the ground that the merger approved by the court in Popkin had been required by the terms of a settlement in a prior case and therefore fulfilled the corporate purpose test. 533 F.2d at 1291.

Rehearing en banc was denied in Green and Marshel. See Green v. Santa Fe Indus., Inc., 533 F.2d 1309 (2d Cir. 1976).

In Bryan v. Brock \& Blevins Co., 490 F.2d 563, 568-71 (5th Cir.), cert. denied, 419 U.S. 844 (1974), the Fifth Circuit had discussed a similar corporate purpose test in the context of a 10b-5 action. Since adequate support was found in state law and general equity principles, however, the court's holding in favor of the plaintiff minority sharehoider was not entirely dependent on the application of that test, as it was in Green and Marshel.

7. Section 10(b) of the Securities Exchange Act of 1934 provides:

It shall be unlawful for any person ...

(b) To use or employ, in connection with the purchase or sale of any security ... any manipulative or deceptive device or contrivance in contravention of such rules and reguiations as the Commission may prescribe as necessary or appropriate in the public interest or for the protection of investors. 15 U.S.C. $\S 78 j$ (1970).

Rule 10b-5, promulgated under this section, provides:

It shall be unlawful for any person, directly or indirectly, by the use of any means or instrumentality of interstate conmerce, or of the mails, or of any facility of any national securities exchange,

(1) To employ any device, scheme, or artifice to defraud,

(2) To unake any untrue statement of a material fact or to ounit to state a material fact necessary in order to make the statements made, in the light of the circumstances under which they were made, not misieading, or

(3) To engage in any act, practice, or course of business which operates or would operate as a fraud or deceit upon any persou, in connection with the purchase or sale of any security. 17 C.F.R. $\$ 240.10 b-5$ (1975).

The SEC adopted rule 10b-5 to fill a perceived gap in the protection of sellers of securities. Buyers had been specifically provided for by section 17 of the Securities Act of 1933,15 U.S.C. $\$ 77 q(1970)$. The language of rule $10 \mathrm{~b}-5$ is substantially the same as that of section 17. At the time it was promulgated, the SEC expressed no intent to create a private right of action. It was assumed that the rule would be used by the SEC primarily as authority for injunctions in connection with its enforcement actions. By 1947 a federal court had implied a private right of action. Kardon v. National Gypsum Co., 73 F. Supp. 798 (E.D. Pa.), modified on other grounds, 83 F. Supp. 613 (E.D. Pa. 1947). The Supreme Court acknowledged the private right in its second case involving 10b-5, Superintendent of Ins. v. Bankers Life \& Cas. Co., 404 U.S. 6, 13 n.9 (1971). For specific comments by one of the drafters of rule $10 \mathrm{~b}-5$ on the events surrounding its adoption, see Conference on Codification of the Federal Securities Laws, 22 Bus. LAw. 793, 922 (1967). See generally 1 BRomBERG $\$ \$ 2.2$ (400-450); 6 Loss 3869-73.

8. This attitude appears also to extend to other sections of the securities laws. 
The trend toward liberal interpretation of section $10(\mathrm{~b})$ and rule $10 \mathrm{~b}-5$ which has einerged in the courts of appeals over the last decade ${ }^{8}$ has been premised largely upon the view that the securities statutes are reinedial in nature and therefore inust be construed flexibly to protect investors. ${ }^{10}$ With respect to section $10(\mathrm{~b})$, the liberal approach taken by the circuits could clain soine early support from Supreme Court decisions construing other sections of the securities statutes. ${ }^{11}$ The Supreme Court itself took an expansive view of the statute when it first considered rule $10 \mathrm{~b}-5$ in SEC v. National Securities, Inc. ${ }^{12}$ In deciding whether the fraudulent conduct sought to be enjoined by the SEC involved a "purchase" or "sale" of securities, the Court noted that the statutory definitions of those terms were "unhelpful,"13 and concluded that the proper inquiry was whether the "alleged conduct is the type of fraudulent behavior which was meant to be forbidden by the statute and the rule."14 A consideration of the alleged fraudulent conduct by defendants in National Securities led to the conclusion that

See TSC Indus., Inc. v. Northway, Inc., 96 S. Ct. 2126 (1976) (standard of materiality under rule 14a-9); United Housing Foundation, Inc. v. Forman, 421 U.S. 837 (1975) (definition of security).

9. See note 77 infra.

10. See, e.g., Hochfelder v. Ernst \& Ernst, 503 F.2d 1100 (7th Cir. 1974) (10b-5 violated by negligence), rev'd, 96 S. Ct. 1375 (1976); White v. Abrams, 495 F.2d 724 (9th Cir. 1974) (10b-5 cases judged under "flexible duty" standard); Eason v. General Motors Acceptance Corp., 490 F.2d 654 (7th Cir. 1973), cert. denied, 416 U.S. 960 (1974) (standing not restricted to buyers and sellers).

The very existence of a private right of action under $10 \mathrm{~b}-5$ was long a subject of scholarly debate. The leading articles on both sides of the dispute are listed in Ruder, Current Developments in the Federal Law of Corporate Fiduciary Relations-Standing to Sue Under Rule 10b-5, 26 Bus. Law. 1289 n.4 (1971).

11. In SEC v. Capital Gains Research Bureau, Inc., 375 U.S. 180 (1963), Justice Goldberg, writing for the Court, stated: "Congress intended the Investment Advisers Act of 1940 to be construed like other securities legislation 'enacted for the purpose of avoiding frauds,' not technically and restrictively, but flexibly to effectuate its remedial purposes." Id. at 195 (footnote omitted). Tcherepnin v. Knight, 389 U.S. 332 (1967) (Warren, C.J.), a case construing the meaning of the term "security" under section 3(a)(10) of the 1934 Act, also provided support: "[W]e are guided by the familiar canon of statutory construction that remedial legislation should be construed broadly to effectuate its purposes. The Securities Exchange Act quite clearly falls into the category of remedial legislation." $I d$. at 336 (footnote omitted).

12. 393 U.S. 453 (1969). The National Securities case involved an action brought by the SEC under rule 10b-5 rather than a private action. At issue was whether alleged misrepresentations and omissions of material facts communicated to insurance coinpany shareholders in an effort to secure approval of a planned merger fell within the coverage of section 10b and rule 10b-5. In Blue Chip Stamps v. Manor Drug Stores, 421 U.S. 723, 751 n.14 (1975), the Court noted that this earlier decision "established that the purchaser-seller rule imposes no limitation on the standing of the SEC to bring actions for injunctive relief under $\$ 10(\mathrm{~b})$ and Rule 10b-5."

13. 393 U.S. at 466 .

14. Id. at 467 (emphasis added). 
"[t]he broad antifraud purposes of the statute and the rule would clearly be furthered by their application to this type of situation."15 In a dissent which has proved prophetic of the Supreme Court's current approach to $10 \mathrm{~b}-5$ questions, ${ }^{16}$ Justice Harlan expressed concern over the Court's eagerness to read rule 10b-5 "as a sweeping prohibition against fraud in the securities industry when this results in rendering nullities of the other antifraud provisions of more limited scope."17

The initial 10b-5 decision in National Securities was followed by Superintendent of Insurance v. Bankers Life \& Casualty Co. ${ }^{18}$ and Affiliated Ute Citizens v. United States, ${ }^{10}$ both of which employed a flexible interpretation of the rule and expanded the scope of the private right of action. In Bankers Life, the Court applied section 10(b) to a unique fraudulent scheme by holding that the deceptive practice need only "touch" on a sale of securities to be actionable under the federal securities laws; ${ }^{20}$ classic securities fraud need not be an intrinsic part of the sale on which federal jurisdiction is predicated. In Ute, the Court

15. $I d$.

16. See text accompanying notes $22-23$ infra.

17. 393 U.S. at 470 . Justice Harlan identified Judge Jerome Frank and Professors Louis Loss and Milton Cohen as participants in the debate over 10b-5's coverage who had warned against the result which the Court appeared to accept. See Fischman v. Raytheon Mfg. Co., 188 F.2d 783, $788-89$ (2d Cir. 1951) (Frank, J.); 3 Loss 1778-92; Cohen, "Truth in Securities" Revisited, 79 HaRv. L. REv. 1340, 1366, 1370 n.89 (1966). The Harlan dissent cited sections 11(a), 12(2) and 13 of the 1933 Act, 15 U.S.C. $\S \S$ $77 \mathrm{k}(\mathrm{a}), 77 l(2), 77 \mathrm{~m}$ (1970), and section 18 of the 1934 Act, 15 U.S.C. $\$ 78 \mathrm{r}$ (1970), as examples of limited antifraud provisions. Section 11(a) explicitly limits the right of action to purchasers and sellers, while the other sections cited impose procedural limitations which are lacking for actions brought under section 10. Sections 12(2) (operating through the provisions of section $11(\mathrm{e}), 15$ U.S.C. $\$ 77 \mathrm{k}(\mathrm{e})(1970)$ ) and 18 include a security for costs provision absent in section $10(\mathrm{~b})$. See McClnre v. Borne Chemical Co., 292 F.2d 824 (3d Cir.), cert. denied, 368 U.S. 939 (1961); Fischman v. Raytheon Mfg. Co., 188 F.2d 783 (2d Cir. 1951); 1 Bromberg $§ 2.5(2)$. Similarly, sections 13 and 18 operate under a shortened statute of limitations, while $10(\mathrm{~b})$ utilizes the statute of the forum state, which is usually more liberal than that provided by sections 13 and 18. See Emst \& Emst v. Hochfelder, 96 S. Ct. 1375, 1389 n.29 (1976), citing 3 Loss 1773-74.

The importance of these himitations was discussed extensively in Ernst \& Ernst, 96 S. Ct. at 1388-89. They are fundamental to Justice Powell's argument that the Securities Acts are carefully drawn and that expansion of the scope of rule 10b-5 actions should not be allowed to nullify this careful drafting. See notes 39-40 infra and accompanying text.

18. 404 U.S. 6 (1971).

19. 406 U.S. 128 (1972).

20. 404 U.S. at 12-13. The conduct held actionable was a complex scheme whereby a company was fraudulently induced to use its own assets to fnnd a pnrchase of its securities by an outside party. The Court's use of the word "touch" represented a broad construction of the phrase "in connection with" a purchase or sale, found in both section $10(\mathrm{~b})$ and rule 10b-5. See note 7 supra. Justice Douglas, writing for the Court, did not consider 10(b)'s relationship to other sections of the statute. 
held that reliance on a misrepresentation need not be specifically proved by a 10b-5 plaintiff; in the view of the Court, a sufficient showing of reliance is made upon proof of nondisclosure of a "material" fact, defined as information which "a reasonable investor might have considered . . . inportant in the making of [his] decision" to buy or sell shares. ${ }^{21}$

When Justices Powell and Relinquist joined the Court in 1972, the concern over expansion of section $10(\mathrm{~b})$ and rule $10 \mathrm{~b}-5$ expressed by Justice Harlan ${ }^{22}$ in National Securities gamed two powerful spokesmen. Each has recently authored a lengthy majority opinion in an effort to show that a proper interpretation of the statute and rule requires more than an awareness of the remedial purpose of the securities laws. Both stressed the importance of studying the interrelated coinponents of the 1933 and 1934 Acts and the need for respecting the particular remedies and standards of fault which Congress created in those Acts. ${ }^{23}$

In Blue Chip Stamps v. Manor Drug Stores, ${ }^{24}$ the Supreme Court reaffirmed the Birnbaum rule, which mandates that a plaintiff be a

21. 406 U.S. at 153-54. The complaint arose out of the administration of a federal program to partition and distribute the assets of the Ute Tribe between whole-blood and mixed-blood members. As part of the program, mixed-bloods seeking to dispose of their shares in the tribe's oil and mineral rights were required to give first-refusal rights to the whole-blood membership. The fraudulent misstatements consisted of assertions by officers of a transfer agent bank to prospective mixed-blood sellers that the price being offered was the market price, when the latter was in fact significantly higher. In holding that the plaintiffs need not show that they relied on the defendants' nondisclosures, the Court eliminated one of the elements of common law fraud which had been thought to apply to actions under 10b-5. See 3 Loss at 1435-36.

The Court has recently indicated that the language in the case which purported to define "material" is no longer a complete and authoritative statement of the law. TSC Indus., Ine. v. Northway, Inc., 96 S. Ct. 2126, 2132 n.9 (1976).

22. See notes 16-17 supra and accompanying text. Professor Bromberg has recently stated the case even more strongly:

I think it is well to look on $10 \mathrm{~b}-5$ with a hard, realistic eye as being a kind of carte blanche to the federal courts to create what we talked about a few years ago as common law corporate responsibility, and what I would like to suggest seems to be, more broadly, common law standards for financial transactions.

1 think the development has gone on with virtually no statutory basis. That is barely a pretext now . . . .

K. Bialkin \& H. ENBERG, The 10B Series of Rules 50 (Practising Law Institute 1975).

23. See notes $29,39-40$ infra and accompanying text.

24. 421 U.S. 723 (1975). In Blue Chip, plaintiffs, as a result of an antitrust consent decree, were given an opportunity to purchase shares of the Blue Chip Stamp Company at a set price. They did not purchase, allegedly because of an overly pessimistic prospectus which was designed to discourage them so that the shares could be offered to the public at a higher price. 421 U.S. at 726-27. The Ninth Circuit found that plaintiffs had standing to sue, notwithstanding the Birnbaum rule which restricted standing to buyers and sellers. Manor Drug Stores v. Blue Chip Stamps, 492 F.2d 136 (9th Cir. 1973). The court reasoned that the status of an offeree was similar to that of a party with contract rights who is protected under the statutory definition of "buy" 
purchaser or seller of securities in order to have standing to sue under rule $10 \mathrm{~b}-5 .^{25}$ Writing for the Court, Justice Rehnquist traced the rise of the implied private right of action under $10 \mathrm{~b}-5,{ }^{26}$ outlining the development of the Birnbaum rule and its application by the courts of appeals. ${ }^{27}$ He then discussed the "congressional scheme" as reflected by the text of the statute and the available extrinsic evidence. ${ }^{28}$ Despite considerable evidence within the statute to support his position, ${ }^{20}$ Jus-

and "sell." 492 F.2d at 141-42; 1934 Act $\S \S 3$ (a) (13-14), 15 U.S.C. $\S \S 78 c(a)(13-14)$. The Supreme Court reversed in a lengthy opinion. Justice Blackmun argued in dissent that the Court's decision disregarded the broad purpose of the 1934 Act, 421 U.S. at 765, and that the Court's consideration of policy, see notes 31-34 infra and accompanying text, was inappropriate. Id. at 769-71.

25. The Birnbaum rule, established in Birnbaum v. Newport Steel Corp., 193 F.2d 461 (2d Cir.) (A. Hand, J.) cert. denied, 343 U.S. 956 (1952), restricted standing for the private right of action under $10 \mathrm{~b}-5$ to purchasers and sellers of securities. The rule had been extensively criticized by commentators, although it had some supporters. See Boone \& McGowan, Standing to Sue Under SEC Rule I0b-5, 49 TeXas L. REv. 617, 623, 648-49 (1971) (supporting the rule); Lowenfels, The Demise of the Birnbaum Doctrine: A New Era for Rule 10b-5, 54 VA. L. Rev. 268 (1968). For an extensive listing of commentary on the rule, see The Supreme Court, 1974 Term, 89 HaRv. L. Rev. 47, 267 nn.40 \& 41 (1975).

Despite this criticism, the rule had been generally followed. Only the Seventh Circuit had rejected it outright. Eason v. General Motors Acceptance Corp., 490 F.2d 654, 661 (7th Cir. 1973) (Stevens, J.), cert. denied, 416 U.S. 960 (1974). Various exceptions to the rule had evolved in its twenty-year existence. See Gallagher, 10b-5 After Blue Chip Stamps: How Stands the Judicial Oak?, 80 Dick. L. Rev. 1, 8-22 (1975); The Supreme Court, 1974 Term, 89 HARv. L. Rev. 47, 267-68 (1975).

Until Blue Chip, the Supreme Court had consistently refused to grant certiorari on Birnbaum questions, despite the conflict in the circuits. Compare Eason v. General Motors Acceptance Corp., 490 F.2d 654 (7th Cir. 1973), cert. denied, 416 U.S. 960 (1974) (rejecting the rule), with Landy v. FDIC, 486 F.2d 139, 155-56 (3d Cir. 1973), cert. denied, 416 U.S. 960 (1974) (following Birnbaum).

26. See note 7 supra.

27. 421 U.S. at 731-33. See note 25 supra.

28. Id. at 733-36. See note 17 supra.

29. Justice Rehnquist's construction was based on his conviction that the Securities Acts are "carefully drawn." 421 U.S. at 730,733 n.5. Where Congress included a particular provision in one section of the statute and omitted it in a parallel section, Justice Rehnquist would regard the omission as intended by Congress. Contradictions and omissions must, therefore, be carefully noted and respected. The end result of such a construction could be the destruction of the private right of action under those sections, including $10(\mathrm{~b})$, where it is not mentioned explicitly. In discussing the application of this "doctrine of expressio unius est exclusio alterius" to the five general antifraud provisions of the securities statutes and rules (sections $11(\mathrm{a}), 12(2)$ and $17(\mathrm{a})$ of the 1933 Act and rules 15c1-2 and 10b-5), Professor Bromberg noted that the doctrine "has a respectable history and logic." 1 BROMBERg $\$ 2.4(1)$ at 27. He concluded, however, that "the history of $10 \mathrm{~b}-5$ is a massive rejection of this approach." The insistence of Justices Rehnquist and Powell on the importance of this type of statutory construction represents a major change in the method of analyzing 10b-5 questions. See notes 10-11 supra and accompanying text. For a discussion of the doctrine of expressio unius, see 2A A. SUTHERLAND, STATUTORY CONSTRUCTON $\$ \S 47.23-.25$ (4th ed. 1974). 
tice Rehnquist confessed to doubts about his ability to "divine from the language of section 10(b) the express "intent of Congress." "30 Accordingly, in view of the judicially-implied nature of the private action under section 10(b), Justice Rehnquist found it appropriate for the Court to weigh policy considerations in delimiting its bounds. ${ }^{31}$ Finding significant policy reasons for retaining the Birnbaum limitation on 10b-5 actions, he nevertheless acknowledged that the plaintiffs in Blue Chip could be granted relief without causing the problems envisioned under a complete repudiation of the Birnbaum rule. ${ }^{32}$ Justice Rehnquist rejected sucl an expedient, arguing that a narrow decision would leave the "purchaser or seller" requirement open to "endless case-by-case erosion"33 and provide an unsatisfactory rule of liability for future business transactions. ${ }^{34}$

Justice Rehnquist demonstrated the use of this approach in his argument for retaining the Birnbaum rule by noting that the wording of section 10(b)-"in connection with the purchase or sale"-contrasts with the wording of section 17(a), the parallel antifraud section of the 1933 Act- "in the offer or sale" (emphasis added). Section 16(b) of the 1934 Act provides a right of action to recover insider profits to shareholders who have neither purchased nor sold. By contrast, Justice Rehnquist emphasized, the express non-derivative private civil remedies created by Congress in sections 11(a) and 12 of the 1933 Act and sections 9 and 18 of the 1934 Act are "by their terms expressly limited to purchasers and sellers." 421 U.S. at 736 . Justice Rehnquist then concluded that "it would indeed be anamolous to impute to Congress an intention to expand the plaintiff class for a judicially implied cause of action [rule 10b-5] beyond the bounds it delineated for comparable express causes of action." Id.

30. 421 U.S. at 737.

31. Id. Justice Powell's concurrence emphasized the text and legislative history, and the text of the rule, suggesting that he would have decided the case on these factors alone. Id. at 755-57. The concurrence illustrates the contrast between the Powell-Rehnquist approach and the earlier method of $10 \mathrm{~b}-5$ analysis; in response to Justice Blackmun's charge of "callousness toward the investing public," Justice Powell replied that "[o]ur task in this case is to construe a statute." See id. at 760, 762. See also Foremost-McKesson, Inc. v. Provident Securities Co., 423 U.S. 232 (1976) (evincing a similar attitude toward the extension of liability in cases brought under section 16(b) of the 1934 Act, 15 U.S.C. \& 78p (1970)).

32. 421 U.S. at 755. Justice Rehnquist emphasized the threat of "vexatious" litigation prompted by the settlement value of $10 \mathrm{~b}-5$ suits. The vast majority of reported 10b-5 cases, including Marshel and Green, are appeals from a dismissal; such cases are often settled before trial on the merits. See id. at 740; 1 Bromberg $\$ 1.3(2)$. But see Bromberg, Are There Limits to 10b-5?, 29 Bus. LAw. 167 (1974) (suggesting that more cases are being brought to trial). On a related point, the Court expressed concern over the "disruption of normal business activities" caused by frivolous suits. 421 U.S. at 743. This disruption would be increased, according to Justice Rehnquist, by use of the "shifting and highly fact oriented" standard which would accompany abandonment of Birnbaum. Id. at 755. The Court's fear for the instability of the standard which would arise if the Birnbaum rule were rejected was based on its belief that judicial outcomes would "turn largely on whicl oral version of a series of occurrences the jury may decide to credit." Id. at 742.

33. Id. at 754.

34. Id. at 755 . 
In Ernst \& Ernst v. Hochfelder, ${ }^{35}$ the Court held that an allegation of mere neghigent misconduct by the defendant was insufficient to sustain an action under $10 \mathrm{~b}-5 .^{36}$ Delivering the opinion of the Court, Justice Powell found adequate support in the text of section 10 (b) for the conclusion that Congress did not intend that $10(\mathrm{~b})$ remedies be applied except where some forn of scienter was involved. ${ }^{37}$ Although satisfied with his textual analysis, Justice Powell turned to other sections of the statute and the legislative history to determine whether these sources supported the arguments made by the plaintiffs and the SEC. ${ }^{38}$ He found particularly persuasive in this regard the

35. 96 S. Ct. 1375 (1976).

36. Ernst \& Ernst served as accountants to First Securities Company of Chicago, which had allegedly defrauded its clients, including plaintiffs, through the use of false accounts for 24 years. The fraud was discovered in 1968 when the president of First Securities committed suicide, leaving a note which revealed that the company was bankmpt and the accounts were false. Although no record of the false accounts appeared in any of First Securities books and records, plaintiffs contended that a proper audit would have uncovered the fraud by discovering the president's special rule which allowed no one else to open mail addressed to him. $96 \mathrm{~S}$. Ct. at 1378-80.

The Seventh Circuit held that Ernst $\&$ Ernst had a statutory and common law duty of inquiry and that the plaintiffs as beneficiaries of the duty would have a valid action under $10 \mathrm{~b}-5$ if there had been a breach which caused plaintiffs' loss. Hochfelder $v$. Ernst \& Ernst, 503 F.2d 1100 (7th Cir. 1974).

37. $96 \mathrm{~S}$. Ct. at 1391 . Justice Powell used scienter to mean "intent to deceive, manipulate or defraud." Id. He noted that several courts of appeals had held that negligence alone was sufficient to support a private action under 10b-5. Id. n.12; see White v. Abrams, 495 F.2d 724, 730 (9th Cir. 1974) ("flexible duty" standard); Myzel v. Fields, 386 F.2d 718, 734-35 (8th Cir. 1967), cert. denied, 390 U.S. 951 (1968) (intent to deceive not required); Kohler v. Kohler Co., 319 F.2d 634 (7th Cir. 1963) (knowledge not required).

The scienter requirement question is part of a larger debate over the relationship between the elements of common law fraud (i.e., misrepresentation, privity, scienter, causation, inateriality, and reliance) and rule $10 \mathrm{~b}-5$ fraud. Courts have gradually relaxed the requirements for fraud under the rule. See, e.g., Affiliated Ute Citizens v. United States, 406 U.S. 128 (1972); Superintendent of Ins. v. Bankers Life \& Cas. Co., 404 U.S. 6 (1971); White v. Abrams, 495 F.2d 724 (9th Cir. 1974). See Bncklo, Scienter and Rule 10b-5, 67 Nw. U.L. REv. 562 (1972) for a discussion of the diverse treatment courts have given to scienter. Justice Powell, looking directly to the statute, did not discuss the role of common law fraud in Ernst \& Ernst. He found that the text of the statute itself required that scienter be present and thus did not enter the debate over the role of common law fraud under section $10(\mathrm{~b})$. This is consistent with his emphasis on the statute as the foundation of the rule, since the term "fraud" was introduced into rule $10 \mathrm{~b}-5$ but is not found in the statute itself. See uote 58 infra.

38. $96 \mathrm{~S}$. Ct. at 1385-87. As in Blue Chip, the SEC, which has been active in expanding the private right of action, filed an amicus brief for the plaintiffs. See 3 Bromberg $\$ 10(1)$. In his concurrence in Blue Chip, Justice Powell took exception to the Commission's attempt to rewrite the 1934 Act through judicial action. 421 U.S. at 759-60 n.4; see note 49 infra and accompanying text. See also United Housing Foundation, Inc. v. Forman, 421 U.S. 837, 858 n.25 (1975) (SEC criticized for inconsistent positions in case restricting reach of term "security"). 
procedural limitations which Congress placed on the civil remedies which it expressly provided elsewhere in the statute..$^{39}$ In a passage which echoed Justice Harlan's earlier concerns, Justice Powell reasoned that these carefully drawn Congressional limitations would be nullified if the Court made negligent misconduct actionable under 10b-5, with its broad procedural advantages. ${ }^{40}$ In light of his conclusion that the statute and its history gave a clear answer on the negligence issue, Justice Powell noted that the policy considerations mvoked in the Blue Chip decision did not need to be reached. ${ }^{\text {} 1}$

Taken together, Blue Chip and Ernst \& Ernst estabhish a new method for analyzing the proper scope of the private right of action under rule 10b-5. The Court will first examine the statute and the rule; if the answer is unclear from the text, legislative history and other extrinsic evidence will be consulted. Where the Court remains uncertain of the proper construction, it is not clear whether it will weigh policy considerations as it did in Blue Chip. Despite their differences, both Justice Powell and Justice Rehnquist accept the statute as carefully drawn. The implication of this view is that the competing policy choices have already been weighed and decided upon by Congress, and that the Court should therefore limit itself to a careful search for clues to congressional intent, rather than attempt an imdependent reevaluation of policy factors.

Although the flexible approach toward $10 \mathrm{~b}-5$ taken in earlier cases has not been specifically rejected, there is strong evidence that it has fallen from favor. In Blue Chip, Justice Rehnquist acknowledged the Court's prior holdings that rule $10 \mathrm{~b}-5$ should be construed flexibly. ${ }^{42}$ He noted, however, that the private cause of action under $10 \mathrm{~b}-5$ is a judicial creation which inust "be judicially delimited one way or another unless and until Congress addresses the question;"13 hence, the inore

39. $96 \mathrm{~S}$. Ct. at 1387-89. Justice Powell noted, as Justice Harlan had earlier, see note 17 supra, that those bringing suit under sections $11,12(2)$ and 15 of the 1933 Act must post a bond for costs. He also pointed to the reduced statute of limitations in section 13, which applies to those suing under sections $11,12(2)$, and 15 . He stressed that two of these procedural safeguards, the shortened statute of limitations and the security for costs provision of section 11(e), particularly concerned Congress, as they were added to the 1933 Act by amendment in the 1934 Act. See note 29 supra.

40. $96 \mathrm{~S}$. Ct. at 1389 . See notes 17,29 and 39 supra.

41. Id. at 1391 n.33.

42. 421 U.S. at 748-49. See notes 12-21 supra and accompanying text.

43. Id. at 749. Justice Rehuquist's emphasis on the need to delimit the private right of action (described as a "judicial oak which has grown from little more than a legislative acorn," id. at 737) suggests a subtle but basic difference between his approach and that of Justice Powell. See note 31 supra and notes 46-50 infra and accompanying text. This difference is manifest in Justice Rehnquist's eagerness to 
liberal earlier precedent does not "militate . . . against the Birnbaum rule."44 Despite this attempt to harmonize the Blue Chip holding witl the earlier cases, it seems unlikely that Justice Rehnquist would engage in flexible construction of what he considers to be a "carefully drawn" statute. A liberal reading of $10 \mathrm{~b}-5$ would seein particularly foreign to one who believes that "the inexorable broadening of the class of plaintiffs who may sue in this area of the law will ultimately result in more harm than good." $4 \delta$

Justice Powell has attacked the doctrine of flexible interpretation more directly. He began his opinion in Ernst \& Ernst with a carefully formulated statement outlining the distinct purposes of the 1933 and 1934 Acts. $^{48}$ In rejecting the SEC's argument for a flexible interpretation, Justice Powell asserted that the reading of a negligence standard of hability into section $10(\mathrm{~b})$ would be imconsistent with the explicit provision of such a standard in other sections of the Act. ${ }^{47}$ When Congress did choose to provide for negligence liability, it enacted specific procedural safegnards which are lacking in $10(\mathrm{~b}) .^{48}$ Therefore, he concluded, section 10(b) does not provide the protection which Congress apparently felt to be a necessary adjunct to negligence hability. The SEC was criticized for attempting to "add a gloss" to the statutory language by arguing that the Court should focus on the effect of the alleged fraudulent practice on the investor, rather than directing its attention to whether the alleged fraud was negligent or intentional. ${ }^{48}$ The Powell opinion in Ernst \& Ernst stressed the fact that while rule $10 \mathrm{~b}-5$ might be read in the abstract as prohibiting a wide variety of

weigh policy and thereby defeat 10b-5 expansionists on their own ground, while Justice Powell is satisfied with analyzing the statute. See notes 30-34, 37-38 supra and accompanying text. The difference implies that in a close case Justice Powell's careful analysis of the statute might support expansion of $10 \mathrm{~b}-5$ while policy arguments of the sort made by Justice Rehnquist would call for an opposite conclusion.

44. 421 U.S. at 749.

45. Id. at $747-48$.

46. $96 \mathrm{~S}$. Ct. at 1381-82. See text accompanying notes 74-76 infra.

47. Id. at 1388-89. For example, Justice Powell cited section 11 of the 1933 Act, which provides for a private right of action based on a negligence standard. He argued that the express recoguition of such a standard in section 11 "significantly undercuts" the argument for $10(\mathrm{~b})$ negligence liability. For a general discussion of this type of reasoning, see note 29 supra.

48. $96 \mathrm{~S}$. Ct. at 1388-89. See note 39 , supra.

49. $96 \mathrm{~S}$. Ct. at 1383 . Justice Powell appears to be particularly sensitive to the statutory language. His concurrence in Blue Chip seemed to accept the judicial creation of a private right of action under section $10(\mathrm{~b})$ in part because "it was unnecessary to rewrite the precise language of $\$ 10(\mathrm{~b})$ and Rule 10b-5." Blue Chip Stamps v. Manor Drug Stores, 421 U.S. 723, 759 (1975). 
fraudulent practices, the statute is the essential source of rule $10 \mathrm{~b}-5$ 's power, and therefore must set the outer limits of the rule's scope. ${ }^{50}$

The Second Circuit's decisions in Marshel v. AFW Corp..$^{51}$ and Green v. Santa Fe Industries, Inc. ${ }^{52}$ employed a sharply contrasting, highly flexible interpretation of rule $10 \mathrm{~b}-5$. The fuller opinions in Green clearly set forth the bases for the decisions. ${ }^{53}$ Judge Medina, speaking for the court in Green, asserted that

. . Rule 10b-5 must be interpreted and applied so as to accomplish the purpose for which it was intended. That this requires a generous reading is too obvious for comment. ${ }^{54}$

He went on to argue that a finding of fraud under $10 \mathrm{~b}-5$ was not dependent upon the presence of misrepresentation, concluding that an equitable definition of fraud ${ }^{55}$ would include situations in which controlling shareholders breached their "fiduciary duty to deal fairly with

50. $96 \mathrm{~S}$. Ct. at 1390-91. See notes $7 \& 37$ supra and note 58 infra.

51. 533 F.2d 1277 ( $2 \mathrm{~d}$ Cir.), petition for cert. filed, 44 U.S.L.W. 3720 (U.S. June 8, 1976).

52. 533 F.2d 1283 (2d Cir.), petition for cert. filed, 44 U.S.L.W. 3671 (U.S. May $14,1976)$. See notes $5-6$ supra and accompanying text.

53. The Marshel opinion was less explicit than that in Green, but it did employ prior case law which had itself used a flexible construction. See Superintendent of Ins. v. Bankers Life \& Cas. Co., 404 U.S. 6 (1971); Drachman v. Harvey, 453 F.2d 732 (1972); Schoenbaum v. Firstbrook, 405 F.2d 215 (2d Cir. 1968), cert. denied, 395 U.S. 906 (1969).

In general, the analysis which follows will focus on Green; analysis of Marshel would, in the context of this Note, parallel that of Green.

It should be noted that in both Marshel and Green the plaintiff would have had standing under the forced-seller exception to the Birnbaum rule. See Vine v. Beneficial Fin. Co., 374 F.2d 627 (2d Cir.), cert. denied, 389 U.S. 970 (1967). Whether this exception has survived Blue Chip is at least questionable. Allowing the forced-seller exception would seem not to raise the specter of fact-oriented case-by-case erosion of Birnbaum which concerned Justice Rehnquist. In the forced-seller situation, a complaint will not depend entirely on oral testinony, and Birnbaum will itself be satisfied by the formality of completion of the merger, at which time the minority will have exchanged its stock for either the offered price or the appraised price. See notes 24-34 supra and accompanying text. One commentator, however, has already concluded that the forced-seller exception is no longer valid. Gallagher, 10b-5 After Blue Chip Stamps: How Stands the Judicial Oak?, 80 Dick. L. REv. 1, 36-37 (1975).

The Green court did not discuss the possible effect of Blue Chip on the case. The opinion merely noted without discussion that a forced sale was involved. $533 \mathrm{~F} .2 \mathrm{~d}$ at 1287 \& $\mathrm{nn} .3,4$.

54. 533 F.2d at 1287 .

55. Id. at 1289-90. Judge Medina relied on SEC v. Capital Gains Research Bureau, Inc., 374 U.S. 180 (1963), in developing his broad definition of rule 10b-5 fraud:

Fraud, indeed, in the sense of a court of equity properly includes all acts, omissions and concealments which involve a breach of legal or equitable duty, trust, or confidence, justly reposed, and are injurious to another, or by which an undue and unconscientious advantage is taken of another. Id. at 194, quoting Moore v. Crawford, 130 U.S. 122, 128 (1888). 
minority shareholders by effecting [a] merger without any justifiable business purpose."

Judge Mansfield's concurrence in Green generally paralleled Judge Medina's opinion. After noting the potential effects on the securities industry of the use of the short-form merger as a nieans of going private, ${ }^{57}$ he focused on the overall anti-fraud purposes of rule 10b-5. Judge Mansfield's sole reference to the statute consisted of a citation to Bankers Life, im which he observed that that case taught that "[s]ection 10(b) must be read flexibly." 58 The concurrence noted that if public shareholders "are to enjoy the protection intended to be furnished by $10 \mathrm{~b}-5$, that rule must not be interpreted in a technical or niggardly fashion,"59 and acknowledged the Second Circuit's "steady trend toward an expansive view of the reach of the federal securities laws."

It seems clear that the claims advanced by the plaintiffs in Green would be analyzed differently under the narrower interpretive guidelines laid down in Blue Chip and Ernst \& Ernst. One would begin with the "starting point in every case involving the construction of a statute" - "the language itself." Section 10(b) prohibits the use of a "deceptive or manipulative device or contrivance." ${ }^{82}$ To conve within the

56. 533 F.2d at 1291. For recent discussions of the corporate purpose test, see Bryan v. Brock \& Blevins Co., 490 F.2d 563 (5th Cir.), cert. denied, 419 U.S. 844 (1974); Grimes v. Donaldson, Lufkin \& Jenrette, Inc., 392 F. Supp. 1393 (N.D. Fla. 1974). See note 6 supra.

57. 533 F.2d at 1295-96.

58. Id. at 1296-97, quoting Superintendent of Ins. v. Bankers Life \& Cas. Co., 404 U.S. 6,12 (1971):

The recognition that "fraud" as that term is used in $\S 10$ (b) must be interpreted broadly was given further impetus by the Supreme Court's decision in [Bankers Life] where, in holding that fraud forming the basis of a 10b-5 suit need not be intrinsic to the securities transaction itself, the unanimous Court stated that "Section 10(b) must be read flexibly, not techrically or restrictively ...."

In the context of the Powell-Rehnquist analysis, with its heavy emphasis on the text of the statute, it is worthy of note that, contrary to the implication of Judge Mansfield's concurrence, the term "fraud" appears nowhere in the text of section 10(b); rather, it is derived from rule $10 \mathrm{~b}-5$.

59. 533 F.2d at 1296.

60. Id. at 1297.

61. Blue Chip Stamps v. Manor Drug Stores, Inc., 421 U.S. 723, 756 (Powell, J., concurring). The point was re-emphasized in Justice Powell's opinion for the Court in Ernst \& Ernst v. Hochfelder, 96 S. Ct. 1375, 1383 (1976), wherein he quoted his earlier concurrence.

62. See note 7 supra. In order to find deception, one would need to refer to the investor's expectations at the time the stock was purchased, see Voege v. American Sumatra Tobacco Corp., 241 F. Supp. 369 (D. Del. 1965), and argue that the corporation had failed to disclose that the shareholder might be forced to resell his stock to the corporation in a going private transaction. This already tenuous argument is further complicated by the existence of short-form merger statutes in many states, under which 
scope of the statute, a procedure such as that employed in Green inust therefore involve either deception or manipulation. It is difficult to see how going private under a short-form merger statute would constitute a deceptive device in itself. The decision in Green did not rest upon the limited nondisclosure allegations in the complaint; ${ }^{63}$ the court held specifically that "[i]f there is no valid corporate purpose for the merger, then even the most brazen disclosure of that fact to the minority shareholders in no way mitigates the fraudulent conduct."

Absent deception, a decision for a plaintiff under the facts of Green must, under the Blue Chip/Ernst \& Ernst analysis, depend upon a finding that use of the short-form merger to squeeze out minority shareholders constitutes a "manipulative device or contrivance." Justice Powell emphasized in Ernst \& Ernst that "manipulative" "is and was virtually a term of art when used in connection with securities markets . . connot[ing] intentional or willful conduct designed to deceive or defraud investors by controlling or artificially affecting the price of securities." W5 While the construction put upon the term by Justice Powell is hardly apparent from the face of section $10(\mathrm{~b})$, it has considerable support in the legislative history of the statute. Section 9 of the 1934 Act, subtitled "Manipulation of security prices," specifically proscribes a number of stock market activities, notably wash sales, matched buy-sell orders, and the making of false stateinents by brokers. ${ }^{60}$ In testimony regarding a predecessor of section $9,{ }^{67}$ Thomas G. Corcoran, one of the drafters of the 1934 Act stated that that section "embodies a proposal with which few people would disagree"the proscription of the particular manipulative devices enumerated therein. ${ }^{68}$ Addressing himself next to the predecessor of section $10,{ }^{00}$

an investor might be held to be on notice of prospective forced sales. Ernst \& Ernst would also require that a plaintiff show that the corporation intended to deceive him at the time of purchase and that the misrepresentation was part of a plan to go public and then private. $96 \mathrm{~S}$. Ct. at 1383-84.

63. The complaint alleged a failure to disclose the merger plans until after the merger had been effected. 533 F.2d at 1288.

64. Id. at 1292 .

65. $96 \mathrm{~S}$. Ct. at 1384.

66. See 15 U.S.C. \& $78 \mathrm{i}(1970)$.

Wash sales are transactions involving no change in beneficial ownership. Matched orders are orders for the purchase/sale of a security that are entered with the knowledge that orders of substantially the same size, at substantially the same time and price, have been or will be entered by the same or different persons for the sale/purchase of such security. Ernst \& Emst v. Hochfelder, 96 S. Ct. 1375,1386 n.25 (1976).

67. S. 2693 and H.R. 7852, 73d Cong., 2d Sess. $\$ 8$ (1934).

68. Hearings on H.R. 7852 and H.R. 8720 Before the House Comm. on Interstate and Foreign Commerce, 73d Cong., 2d Sess. 110 (1934).

69. S. 2693 and H.R. 7852, 73d Cong., 1st Sess. $\S 9$ (1934), reproduced in 


\section{Corcoran testified that it}

... forbids short-selling and stop-loss orders except in accordance with such regulations as may be prescribed by the Commission. Subsection (c) says, "Thou shalt not devise any other cunning devices."

Of course subsection (c) is a catchall clause to prevent manipulative devices. I do not think there is any objection to that kind of clause. The Commission should have authority to deal with new manipulative devices. ${ }^{70}$

Corcoran's testimony clearly indicates that sections 9 and 10 of the 1934 Act were intended to complement one another. Section 9 proscribes enumerated nnanipulative devices generally agreed to be obnoxious. Section 10 gives further rulemaking power to the Commission to regulate the use of short sales and stop-loss orders, the legitimate utility of which was in issue, ${ }^{71}$ and to proscribe any similar nanipulative devices whose novelty had eluded the ingenuity of the draftsmen.

The above analysis would indicate that the "manipulation" subjected to the Commission's regulation under section $10(\mathrm{~b})$ must be price manipulation of the sanie character as that covered by section 9. Under the Ernst \& Ernst holding, practices not reached by section 10 (b) cannot be violative of rule $10 \mathrm{~b}-5 \mathbf{F}^{72}$ if Justice Powell's definition of "manipulative" is correct, $10 \mathrm{~b}-5$ claims such as those advanced in Green and Marshel must fail absent proof of deception. This restrictive reading of "manipulative" will not, of course, foreclose relief

Hearings, supra note 68 , at 7 . While $\S 9$ (c) of S. 2693 and H.R. 7852 clearly is the lineal ancestor of $\S 10(\mathrm{~b})$, there were significant differences between the enacted and unenacted versions. Compare $\$ 9$ (c) of S. 2693:

[It shall be unlawful for any person, directly or indirectly . . . -]

To use or employ in connection with the purchase or sale of any security . . . any device or contrivance which, or any device or contrivance in a way or manner which the Commission may by its rules and regulations find detrimental to the public interest or to the proper protection of investors. with $\S 10(\mathrm{~b})$ :

[It shall be unlawful for any person, directly or indirectly . . - - ]

To use or employ, in connection with the purchase or sale of any security ... any manipulative or deceptive device or contrivance in contravention of such rules and regulations as the Commission may prescribe as necessary or appropriate in the public interest or for the protection of imvestors (emphasis added).

70. Hearings, supra note 68 , at 115 . See generally 1 BromBERo $\$ 2.2$.

71. This section... relates to matters which a great many people think ought to be absolutely forbidden .... The theory of this bill is that no one yet knows enough about short selling to know whether it should be legislated out of existence, or whether it might not be handled as a possibly useful tool of the market under regulations devised by the Commission. Hearings, supra note 68, at 115.

72. See note 50 supra and accompanying text. 
for all such plaintiffs; it is not uncommon for majority shareholders contemplating going private to omit dividends or misrepresent the corporation's future prospects in an effort to depress the value of the minority's interest and acquire it inexpensively. Plaintiffs thus squeezed out would arguably have a cause of action under $10 \mathrm{~b}-5$, based upon the specific price-manipulative aspects of the transaction. ${ }^{73}$

While withholding federal relief froin a Green-type plaintiff might seem contrary to the policy of the securities statutes as outlined in the earlier cases, that policy itself has been redefined in Ernst \& Ernst. The aim of the securities laws, under Justice Powell's analysis, is not the broad "protection of investors." 74 The purpose of the 1934 Act is limited, rather, to cleansing the market of "inanipulation of stock prices through regulation of transactions upon securities exchanges and overthe-counter markets, and [inposing] regular reporting requireinents on companies whose stock is listed on national securities exchanges."75 Insofar as manipulation and nondisclosure were lacking under the facts of Green and Marshel, this more limited purpose of the 1934 Act was not contravened by the defendants' conduct, however harmful that conduct may have been to the general welfare of the squeezed-out investors. ${ }^{70}$

73. But see Marsh v. Armada Corp., 533 F.2d 978 (6th Cir. 1976). The court held that "manipulation of the market price of the stock by eliminating dividends, with prior full disclosure" did not violate rule 10b-5. Id. at 983, 987. The court distinguished Green and Marshel on the ground that in those cases the shareholders attacked the going private merger itself as fraud. In Marsh the attack was not on the merger, in which the minority shareholders were given a chance to remaiu in the surviving compauy, but on its terms. The Sixth Circuit concluded that deception must be alleged to maintain a claim where the purpose of the merger is not challenged. Id. at 986.

74. See notes $46-50$ supra and accompanying text.

75. $96 \mathrm{~S}$. Ct. at 1382.

76. It is probably unnecessary to weigh broader policy considerations in analyzing Green and Marshel under the Supreme Court's current rubric, as the disposition of the cases seems clear from the language and legislative history of section 10(b). See notes 61-75 supra and accompanying text. Possible policy considerations would, however, include the vexatious litigation problem emphasized by Justice Rehnquist in Blue Chip Stamps v. Manor Drug Stores, 421 U.S. 723 (1975), and mentioned by Justice Powell in Ernst \& Ernst v. Hochfelder, 96 S. Ct. 1375, $1391 \mathrm{n.33}$ (1976). It is feared that elimination of the requirement of misrepresentation or nondisclosure as an element of $10 \mathrm{~b}-5$ fraud would significantly expand litigation in this area, particularly under a vague standard of "equitable fraud." The facts of Green, however, did not present the oral testimony problem wlich was raised by the prospective abandonment of the Birnbaum rule considered in Blue Chip. See note 32 supra.

The Court has also expressed concern for providing clearly delineated legal standards in order to ensure certainty in business transactions. The concepts of equitable fraud and justifiable business purpose employed by the Green court, see notes 55-56 
Prior to Blue Chip and Ernst \& Ernst, minority shareholders excluded from corporate ownership by going private transactions might have expected to obtain federal relief under a steadily expanding rule 10b-5. After Blue Chip and Ernst \& Ernst those expectations would seem to have little hope of realization. In both cases the Supreme Court took a position on the substantive questions which tended to lalt the growth of the private right of action under rule $10 \mathrm{~b}-5 .{ }^{77}$ More im-

supra and accompanying text, do not lend theinselves to the setting of precise boundaries; they involve, rather, case-by-case adjudication, providing less than clear notice of the state of the law. Developments of this sort are clearly contrary to the philosophy of Blue Chip.

The above concepts are interrelated to such an extent that they can scarcely be analyzed as separate entities. Green did, however, involve an independent policy question which was not present in either Blue Chip or Ernst \& Ernst. The transaction in issue was carried out under the Delaware short-form merger statute, DEL. CoDE ANN. tit. $8, \$ 253(1975)$. The state courts had approved this procedure, finding no violation of a fiduciary duty by the majority shareholders. See Stauffer v. Standard Brands, Inc., 41 Del. Ch. 7, 10, 187 A.2d 78, 80 (Sup. Ct. 1962):

The dispute reduces to nothing but a difference of opinion as to value. Indeed it is difficult to imagine a case under the short merger statute in which there could be such actual fraud as would entitle a minority to set aside the merger. This is so because the very purpose of the statute is to provide the parent corporation with a means of eliminating the minority shareholder's interest in the enterprise. Thereafter the former stockholder has only a monetary claim. This power of the parent corporation to eliminate the minority is a complete answer to plaintiff's charge of breach of trust against the directors .... Id. at 80.

See also Application of Del. Racing Ass'n, 42 Del. Ch. 406, 213 A.2d 203 (Sup. Ct. 1965).

Green raised the question of the relationship between federal securities statutes and state law governing fiduciary relationships-the extent to which a federal court can redefine the boundaries of such corporate relationships after a state has expressly approved a method of dealing. While this may be in part a question of preemption, it is also an aspect of the question of federal-state comity. Where, as in the case of section $10(b)$, the federal statute is not clear in its reach, then this factor should at least give pause to a federal court before a federal remedy is expanded at the expense of state law.

77. Blue Chip and Ernst \& Ernst may signal a halt to the growth of federal corporate common law based on section $10(\mathrm{~b})$ and rule $10 \mathrm{~b}-5$, see note 22 supra, a development which had been generally recognized. See Drachman v. Harvey, 453 F.2d 722, 729 (1971), rev'd on other grounds on rehearing en banc, 453 F.2d 736 (2d Cir. 1972); In the Matter of Cady, Roberts \& Co., 40 S.E.C. 907 (1961) (Cary, Commissioner); Loss 3875 (Supp.); Friendly, In Praise of Erie-And of the New Federal Common Law, 39 N.Y.U.L. REv. 383, 413 (1964). In most instances the results of this expanding federal jurisdiction were applauded, as it seemed the most equitable response to the increasing laxity of state corporate regulation. See Bahlman, Rule 10b-5: The Case for its Full Acceptance as Federal Corporation Law, 37 U. CIN. L. Rev. 727, 731 (1968); Jennings, Federalization of Corporation Law: Part Way or All the Way, 31 Bus. Law. 991 (1976); Loss, The American Law Institute's Federal Security Code Project, 25 Bus. Law. 27, 34 (1969). Nonetheless, there was concern that "the way the courts have proceeded is . . . offensive occasionally to one's sense of the integrity of the legislative process." Loss, Wrap-Up, 31 Bus. LAw. 1193, 1195 (1976).

The Supreme Court's current position lends new emphasis to the importance of the 
portantly, the Court demonstrated that it will no longer accept the equity-oriented, flexible approach which the lower courts have followed in expanding the scope of section 10 (b) and rule 10b-5. As a replacement the Court has substituted a tightly reasoned method of analysis which rests firmly on the language of the statute and the intent with which the language was used by Congress.

The Court's current approach to $10 \mathrm{~b}-5$ questions apparently does not threaten the continued existence of the private right of action under rule 10b-5. However, its position does reflect the concerns expressed by the early cases and the commentators over the need for harmonizing the remedy provided by the private right of action under $10 \mathrm{~b}-5$ with the specific remedies provided in the 1933 and 1934 Acts. These concerns had been ignored by the Supreme Court in its previous $10 \mathrm{~b}-5$ cases. The Court's new empliasis on a strict construction of the statute promises to have a profound effect on future actions brought under.rule 10b-5. As for those who had hoped to obtain federal rehief in a going private situation, it appears that they will have to wait for some action by Congress while continumg to rely on existing state remedies.

legislative role. The next step may lie in the direction of congressional consideration of a Federal Securities Code. The ALI's work on such a code has already produced three drafts which would codify over 20 changes in the 10b-5 area. See id. at 1196-97. 